\title{
Corporate Social Responsibility in SAARC Countries: A Study on Commercial Banks
}

\author{
Dr. S.M.Mahbubur Rahman*1 Jenepha Eyesmin ${ }^{2}$ \\ 1.Associate Professor, Department of Business Administration, \\ Noakhali Science and Technology University, Noakhali, Bangladesh. \\ 2.Lecturer, Department of Business Administration, Noakhali Science and Technology \\ University, Noakhali, Bangladesh.
}

\begin{abstract}
It is needless to mention that there is great potential area for regional cooperation among south Asian nations. Since the formation of the South Asian Association of Regional Cooperation (SAARC) in the year 1985 discussion form time to time for future cooperation among them has taken place. The scope of regional cooperation had been identified in twelve areas: (i) agriculture; (ii) health and rural development; (iii) meteorology; (iv) telecommunication; (v) postal services; (vi) transport; (vii) scientific and technological development; (viii) sports; (ix) art and culture; (x) prevention of drug trafficking and abuse; (xi) women and development and (xii) education. This paper attempts to focus upon how and what way Corporate Social Responsibility (CSR) practices are being discharged by the banking sector of the countries involved in the SAARC. The study based on secondary data. Secondary data have been collected from different published sources. The study observed that there is a similarity among SAARC countries sectors of national involvements of CSR initiatives. By CSR activities, every bank has ensured social development. The study recommended that banks should extend their CSR activities in less privileged areas rather than concentrate in resource rich areas.

Keywords: Commercial Bank, Corporate Social responsibility and SAAR
\end{abstract}

DOI: $10.7176 / \mathrm{EJBM} / 11-3-14$

\section{Prelude}

This paper attempts to focus upon how and what way Corporate Social Responsibility (CSR) practices are being discharged by the banking sector of the countries involved in the South Asian Association of Regional Cooperation (SAARC). It is needless to mention that there is great potential area for regional cooperation among south Asian nations. Since the formation of the SAARC in the year 1985 discussion form time to time for future cooperation among them has taken place. The scope of regional cooperation had been identified in twelve areas: (i) agriculture; (ii) health and rural development; (iii) meteorology; (iv) telecommunication; (v) postal services; (vi) transport; (vii) scientific and technological development; (viii) sports; (ix) art and culture; (x) prevention of drug trafficking and abuse; (xi) women and development and (xii) education. ${ }^{1}$ The SAARC countries mainly suffer from the common problems such as poverty, unemployment, inflationary pressure, unfavorable trade balance, high budget deficits and low growth rates. Although common problems, the policies that have been espoused contradictory to one another. The policy issues were more competitively natured than complementary. It originated from historical facts that solving their problems through competition among themselves was better. The SAARC Nations has now believed that it would resolve their problems i.e. poverty, unemployment, inflation and low rate of growth, by cooperating among themselves. "The mutual fear and apprehensions disappear, to better their economies. After assessing and analysing the solution to their problems becomes more apparent that there are more areas of cooperation than areas of conflict" (Gautam \& Anju, 2014). There are various sectors playing important role for economic development of SAARC countries, banking sector is one of them. "Banks are mainly service rendering organization. They do not as such produce physical goods and any tangible products. Therefore, their process of funding and operating, marketing and distribution of service as such do not any harm to the people in particular, society and its environment at a large. Even their 'final disposal' is unlikely to contribute as such any harmful effect to environment, like tangible goods producing sector. Most of the business in our society operate and reach to customer through different channel but banks have more direct contact with people and consumer in providing their services, thus, their activities have a direct reflection or impact upon the people who form the part of their clientele base" (Haldar \& Rahman, 2015). Every banking organization is ethically responsible to their stakeholders and its society. In fulfilling these responsibilities business organizations have taken different strategy, CSR is one of them. Every banking organization main purpose is earning profit without any destruction or harm of its stakeholders or society at large (Haldar \& Rahman, 2016). Carroll (1991) was first advocated the idea of CSR being a social obligation. His CSR pyramid is one of the best reliable CSR models that present organizations social responsibility as comprising economic, legal, ethical and philanthropic responsibility. Carroll said that the main purpose of a business is earning profit,

\footnotetext{
${ }^{1}$ SAARC: Its Evolution, Objectives, Constraints/Challenges and Prospects.
} 
which is called economic motive. By legal responsibility, business will follow all business related rules and regulations. Ethical responsibilities reflected a moral concern of business to its stakeholders and society. Finally, philanthropic responsibilities determine that business will engaging in varies programs to improve human welfare and goodwill. The World Business Council for Sustainable Development (WBCSD, 2000) defined Corporate social responsibility is the continuing commitment by business to behave ethically and contribute to economic development while improving the quality of life of the workforce and their families as well as the local community and society at large. From this sequence, for assessment business impacts on environment and society a set of globally acknowledged are available for business organizations such as, ISO 26000 were prepared by ISO working group on Social Responsibility, GRI, UNGC, ISO 14000 for environmental management system, SA 800 for social accountability standards, PSESS by International Financial Corporation. In this connection, the present paper endeavors an insight in to CSR activities of Commercial banks in SAARC countries.

\section{Literature Review}

\subsection{SAARC}

The South Asian Association for Regional Cooperation (SAARC) was formed under Article 52 of the United Nations' Charter providing existence of regional arrangements or agencies for dealing with such matters, relating to the maintenance of international peace and security with the purpose and principles of UN charter. ${ }^{1}$

It was established on 8th December, 1985 after about four and half years of its preparation. The basic aim of the Association is to accelerate the process of economic and social development in member countries through joint action in the agreed areas of cooperation. The region of SAARC lies in the South Himalayas surrounded by Hindu Kush Mountains. ${ }^{2}$

The very first proposal for establishing a framework for regional integration in South Asia was made by the late president of Bangladesh, Ziaur Rahman, on May 2, 1980. Prior to this, the idea of South Asian integration was discussed in at least three conferences: the Asian Relations Conference in New Delhi in April 1947, the Baguio Conference in the Philippines in May 1950, and the Colombo Powers Conference in April 1954. The governments of Pakistan, Bangladesh, Bhutan, India, Maldives, Nepal, and Sri Lanka formally adopted its charter providing for the promotion of social, economic and cultural development within the South Asian region and also for friendship and cooperation with other developing countries. Its seven founding members were Bhutan, India, Sri Lanka, Maldives, Nepal, Pakistan, and Bangladesh while Afghanistan joined the organization in 2007. Observer states include USA, Australia, China, Japan, South Korea, Myanmar, Mauritius, Iran and European Union. Meetings of heads of state are usually held on annual basis and meetings of foreign secretaries twice a year. ${ }^{3}$

The region is of strategic importance between the east and west with respect to defense, trade, transport population growth and economic development particular for India directly and indirectly. The Indian Ocean plays a vital role in defense, trade and water transport is in the proximity of the majority of South Asia countries. The SAARC region is a landmass of 3.30 percent of the world and has one-fifth of the population. All the SAARC countries can be categorized into different groups. Firstly, there are two land-locked countries namely Bhutan and Nepal. Secondly, there are two Islands such as Sri Lanka and Maldives and thirdly, the three countries, India, Pakistan and Bangladesh which have the Indian Ocean in the South and South West and the Indo-Gangatic plains stretching along these countries. Majority of the people in SAARC countries depend on agriculture and have poor education, lack in science and technology as well as suffer from over-population. Most of the countries depend on the developed countries for aid and trade. ${ }^{4}$

The South Asian Association for Regional Cooperation was formed on 8th December 1985 as the first step towards Regional Corporation. In 1995 a decade after the formation of SAARC, the South Asian Free Preferential Trading Agreement (SAPTA) was launched at the end of year. The year 2001 was declared as the deadline to finalise a treaty for the South Asian Free Trade Association (SAFTA). The SAARC seven countries signed a treaty that would lead to free trade and movement of goods paving the way for South Asian Economic Union along the lines of EU in future. The South Asian Free Trade Association (SAFTA), in the treaty seeks to remove trade barriers, phased elimination of tariffs and establishment of a ministerial level mechanism for administering the treaty and dispute settlement among members. This treaty was to come into operation by January 1, 2006. In fact, the exchange of mutual experience among the countries is more relevant, cheap and cost effective and provides a vast scope for mutual cooperation in various areas. Mostly agriculture will continue to

\footnotetext{
${ }^{1}$ Charter of the United Nations (December, 2006) "Regional Arrangements, ” Published by the United Nations

Department of Public Information, New York- 10017, p 34.

${ }^{2}$ SAARC: Its Evolution, Objectives, Constraints/Challenges and Prospects.

${ }^{3}$ Irum ,S., (2013), South Asian Association for Regional Cooperation (SAARC): Its Role, Hurdles and Prospects, IOSR Journal Of

Humanities And Social Science, Volume 15, Issue 6.

${ }^{4}$ SAARC: Its Evolution, Objectives, Constraints/Challenges and Prospects.
} 
dominate these economies for many years to come. The economy development such as food for growing population, fodder for livestock, raw material and market for industries are the main market goods. ${ }^{1}$

\subsection{Principles of SAARC}

a. Cooperation within the framework of the Association is based on respect for the principles of sovereign equality, territorial integrity, political independence, noninterference in the internal affairs of other states and mutual benefit.

b. Such cooperation is to complement and not to substitute bilateral or multilateral cooperation.

c. Such cooperation should be consistent with bilateral and multilateral obligations of the member states.

d. Decisions at all levels in SAARC are taken on the basis of unanimity.

e. Bilateral and contentious issues are excluded from its deliberations. ${ }^{2}$

\subsection{Objectives of SAARC}

The objectives, principles and general provisions, as mentioned in the SAARC Charter, are as follows:

i. To promote the welfare of the peoples of South Asia and to improve their quality of life;

ii. To accelerate economic growth, social progress and cultural development in the region and to provide all individuals the opportunity to live in dignity and to realise their full potentials;

iii. To promote and strengthen collective self-reliance among the countries of South Asia;

iv. To contribute to mutual trust, understanding and appreciation of one another's problems;

v. To promote active collaboration and mutual assistance in the economic, social, cultural, technical and scientific fields;

vi. To strengthen cooperation with other developing countries;

vii. To strengthen cooperation among themselves in international forums on matters of common interests; and

viii. To cooperate with international and regional organizations with similar aims and purposes. ${ }^{3}$

\subsection{Objectives}

The objectives of this study are;

- To know the present positions of CSR activities of commercial banks in SAARC countries.

- To identify aspects of CSR activities of commercial banks in SAARC countries.

- To identify sectors of CSR initiatives of commercial banks in SAARC countries.

\subsection{Methodology}

The study based on secondary data. Secondary data have been collected from Websites of all commercial banks in SAARC countries, Published reports, Articles and Annual reports of respective banks of SAARC countries. The all banks with corporate websites in each of the Eight SAARC countries were analysed. The websites of each bank were examined for any CSR activities. Where such activity was found, the banks were labeled 'CSR companies' and the CSR web entries were subjected to further analysis. The CSR of these companies was classified in various ways: its extent; its institutionalisation (in terms of dedicated CSR organization and report); its waves (i.e. community involvement, socially responsible products and processes; socially responsible employee relations); and the combinations of issues addressed and modes deployed.

\section{Banking sector CSR in SAARC Countries}

Most of the business is in our society operating and reach to the customers through different channels but banks have more direct contact with people and consumer in providing their services. Thus, their activities have a direct link to people and reflection or impact upon the people who, in the one hand becomes the suppliers of resources and at the same thing becomes use of banking services on the other forming the part of their clientele base $^{4}$. Different sectors have played important role for economic development of SAARC countries, banking sector is one of them. "In India, the concept of CSR is governed by clause 135 of the Companies Act, 2013, which was passed by both Houses of the Parliament, and had received the assent of the President of India on 29 August 2013. The CSR provisions within the Act is applicable to companies with an annual turnover of 1,000 crore INR and more, or a net worth of 500 crore INR and more, or a net profit of five crore INR and more" (Gautam \& Anju, 2014). The new rules, which will be effect from the fiscal year 2014-15 onwards and also require companies to set-up a CSR committee which consisting of their board members, with including at least

\footnotetext{
${ }^{1}$ Iqbal, SAARC: Origin, Growth, Potential and Achievements.

2 "South Asian Association for Regional Cooperation (SAARC), " http://actrav.itcilo.org/actravenglish/ telearn/global/ilo/blokit/saarc.htm\#Objectives.

${ }^{3}$ Iqbal, SAARC: Origin, Growth, Potential and Achievements, pp7.

${ }^{4}$ Haldar and Rahman "An insight into corporate social responsibility practices of commercial banks in Bangladesh", Bangladesh Research Publications Journal, (2014), Vol. 10, Issue. 1, pp.25-32.
} 
one independent director. The Act persuades companies to spend at least $2 \%$ of their average net profit in the prior three years on CSR activities. The ministry's draft rules, that have been put up for public comment, as per the books of accounts net profit define as the profit before tax, profits will not include arising from branches outside India. The Act lists out a set of eligible CSR activities under CSR Act. After seeking board approval, Companies may apply these activities taking into account the local conditions. The indicative CSR activities which can be undertaken by a company under CSR have been identified Schedule VII of the Act.

\section{Data Analysis}

There are eight countries in SAARC region. The study based on secondary published data. Data has been collected respective countries CSR related web side and respective banks' published annual reports and CSR reports.

Table 01: CSR aspect of banking sector in SARRC Countries

\begin{tabular}{|l|l|l|l|l|l|l|l|l|}
\hline Factors/ Aspects & IND & BD & PK & AFG & NEP & MAD & BHU & SIL \\
\hline Act or regulation for CSR. & Y & N & Y & N & N & N & N & N \\
\hline Guideline for CSR & N & Y & Y & N & N & N & Y & N \\
\hline Board/ committee for CSR & Y & Y & Y & N & N & Y & N & Y \\
\hline Monitoring of CSR & Y & Y & Y & N & N & Y & N & Y \\
\hline Disclosed CSR detail in Annual reports & Y & Y & Y & Y & P & Y & Y & Y \\
\hline Published separate CSR report & P & P & N & N & N & N & N & N \\
\hline Follow Global standard of CSR & P & P & P & P & P & P & P & P \\
\hline CSR department & Y & Y & Y & N & N & N & N & N \\
\hline CSR vision and strategy & Y & Y & Y & Y & N & Y & N & N \\
\hline Central bank published review of CSR report. & N & Y & N & N & N & N & N & N \\
\hline CSR activities audit & Y & Y & Y & N & N & N & N & N \\
\hline Tax rebate facilities on CSR expenditure. & N & Y & N & N & N & N & N & N \\
\hline Mandatory CSR & Y & N & N & N & N & N & N & N \\
\hline
\end{tabular}

Source: Respective banks' annual reports and CSR reports ( $\mathrm{Y}=\mathrm{Yes}, \mathrm{N}=\mathrm{No}$, and $\mathrm{P}=\mathrm{Partial})$

Act or Regulation for CSR: Above Table 01 shows that only 2 countries out of 8 countries, (India and Pakistan) have CSR Act and Regulation. In 2009, Indian Government has issued Guideline on Social Responsibility for Central Public Sector Enterprise. In 2012, Lok Shaba has passed 'The Company Bill 2013' and made CSR mandatory for certain category of companies depending on their volume of business or profit. In response to the Committee's overwhelming concerns on the extent of Corporate Social Responsibility (CSR) being undertaken by corporate and the need for a comprehensive CSR policy, the Ministry of Corporate Affairs have agreed that the Bill may now include provisions to mandate that every company having [(net worth of rupees 500 crore or more, or turnover of rupees 1000 crore or more)] or [a net profit of rupees 5 crore or more during a year] shall be required to formulate a CSR Policy to ensure that every year at least $2 \%$ of its average net profits during the three immediately preceding financial years shall be spent on CSR activities as may be approved and specified by the company (Hand Book on CSR, 2013). For CSR activities, Pakistan government has published a CSR guideline namely "Corporate Social Responsibility Voluntary Guideline-2013". The Guidelines are being issued in exercise of powers under section 506B of the Companies Ordinance, 1984. According to guideline every business organization/ company will contribute $1 \%$ to $2 \%$ of profit for CSR expenditure every year.

CSR Guideline: Above Table 01 shows that 3 countries, out of 8 countries have CSR guideline. They have followed this guideline for implementation CSR activities. One country (Pakistan), out of three countries, said guideline has mentioned percentage of profit for CSR expenditure but rest two countries not mentioned percentage of profit for CSR expenditure. They have mentioned said guideline, every bank will be contributed a certain percentage of profit for CSR contribution.

Board/ Committee for CSR: Banking sector in SAARC countries for operating CSR activities fives countries' banks' have separate CSR board or CSR committee. CSR activities have operated according to board or committee advice. Every year board will determine budget and areas or projects of CSR.

Monitoring of CSR: Five countries, out of eight countries have CSR activities monitoring system. Monitoring committee will ensure proper utilization of allocated fund of CSR activities. They identify different CSR project and identify paper base CSR initiatives.

Disclosed CSR detail in Annual reports: Banking sector in SAARC countries, every bank has disclosed CSR activities in annual report.

Published separate CSR report: Two countries, out of eight countries have published separate CSR report yearly but these two countries few banks published separate annual reports.

Follow Global Standard of CSR: For assessment business impacts on environment and society a set of globally 
acknowledged are available for business organizations such as, ISO 26000 were prepared by ISO working group on Social Responsibility, GRI, UNGC, ISO 14000 for environmental management system, SA 800 for social accountability standards, PSESS by International Financial Corporation. Very bank has followed these global standards for CSR initiatives in SAARC countries.

CSR department: The CSR department will be responsible for preparing a detailed plan on CSR activities, including the expenditure, the type of activities, roles and responsibilities of various stakeholders and a monitoring mechanism for such activities. The CSR department can also ensure that all the kinds of income accrued to the company by way of CSR activities should be credited back to the community. Three countries (India, Bangladesh, Pakistan), out of eight countries' banks have CSR department.

CSR vision and strategy: A good CSR practice requires that a company that is serious about its CSR should develop a long-term (three to five years) vision and strategy which is reviewed annually and the activities and budgets are planned on an annual basis. An effective CSR strategy should articulate: who it wishes to address i. e. the target group, where it wishes to work i. e. the geography, what sectors or issues it wishes to address. Five countries' banks' have CSR vision and CSR strategy, out of eight countries banks in SAARC countries.

Above Table 01 also shows that only one country (Bangladesh), out of eight countries Central bank has published annual CSR initiatives report, two countries (India and Pakistan) have separate CSR audit committee, one country (Bangladesh), every bank's enjoyed tax rebate facilities for CSR expenditure and one country (India) has mandatory CSR according to company act 2013.

Table 02: Flow of CSR reporting of Commercial banks in SAARC Countries

\begin{tabular}{|l|l|l|l|l|}
\hline Country & $\begin{array}{l}\text { Number of } \\
\text { Banks }\end{array}$ & $\begin{array}{l}\% \text { of CSR } \\
\text { reporting in Banks }\end{array}$ & CSR aspect & Base of CSR \\
\hline India & 89 & 100 & Mandatory & $\begin{array}{l}\text { Companies Act, 2013 after, Corporate } \\
\text { Social Responsibility Rules, 2014 }\end{array}$ \\
\hline Bangladesh & 52 & 100 & Voluntary & CSR Guide line \\
\hline Pakistan & 39 & 100 & Voluntary & CSR ordinance, 1982 \\
\hline Sri Lanka & 25 & 80 & Voluntary & Own observation \\
\hline Afghanistan & 20 & 75 & Voluntary & Own observation \\
\hline Nepal & 32 & 60 & Voluntary & Own observation \\
\hline Bhutan & 12 & 65 & Voluntary & Own observation \\
\hline Maldives & 07 & 95 & Voluntary & Own observation \\
\hline
\end{tabular}

Source: Respective banks' annual reports and CSR reports

The published reports were investigated for reporting of CSR policies or practices. Where evidence was found, the respective banks were designated CSR reporting. The results are presented in above Table 02 . There are eight countries in SAARC, only three countries all banks have reported CSR activities and other five countries all banks have not reported CSR activities. Here, Afghanistan, Nepal and Bhutan on average 30 percent banks have not reported CSR activities. The Table 02 also shows that there second is a great variation in the penetration of CSR among our selected countries. The proportion of CSR banks in India, Bangladesh and Pakistan 100 percent. This gives clear substance to the view that there is no relation among SAARC countries on pattern of CSR reporting. One country, out of eight countries CSR activities have operated on the mandatory basis and other voluntary basis. Above Table 02 shows that most of the SAARC countries have operated CSR initiatives on the voluntary basis.

Table 03: The extent of CSR reporting in Annual report of banks

\begin{tabular}{|l|l|l|l|}
\hline \multirow{2}{*}{ Country } & \multicolumn{3}{|c|}{ CSR reporting by Banks } \\
\cline { 2 - 4 } & Minimal (1to2 pages) & Medium(3to10 pages) & Extensive(Over 10 pages) \\
\hline India & 45 & 55 & 0 \\
\hline Bangladesh & 10 & 83 & 07 \\
\hline Pakistan & 75 & 25 & 0 \\
\hline Sri Lanka & 90 & 10 & 0 \\
\hline Afghanistan & 100 & 0 & 0 \\
\hline Nepal & 60 & 0 & 0 \\
\hline Bhutan & 40 & 0 & 0 \\
\hline Maldives & 80 & 05 & 0 \\
\hline
\end{tabular}

Source: Respective banks' annual reports and CSR reports

We investigated the extent of coverage that each CSR bank devoted to its CSR reporting. The point here was to distinguish those which devote it relatively extensive attention from those who treat is more cursorily. It is assumed here that, in general terms, the greater the extent of the reporting, the more engaged the bank is with CSR and the more seriously it is taken therein. It is difficult to come up with a uniform unit of analysis with which to precisely specify the extent of CSR reporting. This is because of the range of website reporting styles 
and the fact that whilst some of the reports were in the context of general bank communications, others were in dedicated reports. We simply distinguish banks whose extent of reporting was: 'minimal' (i.e. one to two pages); 'medium' (i.e. three to ten pages); 'extensive' (i.e. over ten pages). Table 03 indicated the percentages of banks for each country which provided minimal, medium and extensive CSR reporting. The picture is of a wide range of experience, from Bangladesh where 83 percent medium and 07 percent extensive of CSR reporting. In India, 55 percent banks medium, 45 percent banks minimal but no extensive of CSR reporting. Only one in eight SAARC countries banks CSR reported at the extensive level. Overall, though, the percentage of banks reporting their CSR extensively and medium were relatively low. Most of the SAARC countries banks have reported CSR minimal level.

Table 04: Proportion of Banks with Dedicated CSR Report

\begin{tabular}{|c|c|c|}
\hline Country & Dedicated CSR Report & \\
\hline India & At least $2 \%$ & Company act 2013 \\
\hline Bangladesh & $3.25 \%$ & Annual Report \\
\hline Pakistan & $1 \%-2 \%$ & Company Ordinance, 1982 \\
\hline Sri Lanka & No mention & \\
\hline Afghanistan & No mention & \\
\hline Nepal & No mention & \\
\hline Bhutan & No mention & \\
\hline Maldives & No mention & \\
\hline
\end{tabular}

Source: Respective banks' annual reports and CSR reports

Above Table 04 shows that 3 countries, out of eight countries bank have mentioned percentage of CSR expenditure of net income. In India, banks have contributed CSR expenditure on basis of Company act 2013, minimum percentage 2 percent but applied some conditions. In Bangladesh, there is no act for CSR and Government not mentioned average percentage of profit after tax for CSR expenditure but every bank has mentioned their CSR report amount of CSR expenditure. In Pakistan, Government has mentioned in the Company Ordinance, 1982 , section 506B that every business organization will contribute $1 \%$ to $2 \%$ of their net income for CSR expenditure. But rest of SAARC countries banking organization and Government have not mentioned any percentage of net income for CSR contribution.

Table 05: National Involvements of CSR

\begin{tabular}{|l|l|l|l|}
\hline \multirow{2}{*}{ Country } & \multicolumn{3}{|c|}{ National Involvements of CSR } \\
\cline { 2 - 4 } & Society relations & Employee relations & Total \% \\
\hline India & 95 & 05 & 100 \\
\hline Bangladesh & 95 & 05 & 100 \\
\hline Pakistan & 90 & 10 & 100 \\
\hline Sri Lanka & 80 & 10 & 100 \\
\hline Afghanistan & 90 & 10 & 100 \\
\hline Nepal & 95 & 05 & 100 \\
\hline Bhutan & 80 & 20 & 100 \\
\hline Maldives & 85 & 15 & 100 \\
\hline
\end{tabular}

Source: Respective banks' annual reports and CSR reports

Above Table 05 shows that there is a similarity among all SAARC countries sectors of national involvements of CSR initiatives. Every countries bank's have emphasizes on social development than employee welfare. By CSR activities, every bank has ensured social development. Because "Most of the business is in our society operate and reach to the customers through different channels but banks have more direct contact with people and consumer in providing their services. Thus, their activities have a direct link to people and reflection or impact upon the people who, in the one hand becomes the suppliers of resources and at the same thing becomes use of banking services on the other forming the part of their clientele base" (Haldar \& Rahman, 2014). 
Table 06: CSR Penetration and Social development in SAARC Countries

\begin{tabular}{|c|c|c|c|c|c|c|c|}
\hline \multirow[t]{2}{*}{ Country } & \multicolumn{7}{|c|}{ CSR Penetration and Social development } \\
\hline & ED & $\mathrm{HE}$ & $\mathrm{DR}$ & PSL & END & Others & Total \\
\hline India & 20 & 19 & 15 & 17 & 04 & 25 & 100 \\
\hline Bangladesh & 24 & 23 & 20 & 15 & 05 & 13 & 100 \\
\hline Pakistan & 26 & 20 & 15 & 10 & 03 & 26 & 100 \\
\hline SriLanka & 23 & 19 & 20 & 17 & 05 & 26 & 100 \\
\hline Afghanistan & 25 & 20 & 19 & 15 & 02 & 19 & 100 \\
\hline Nepal & - & - & - & - & - & - & 100 \\
\hline Bhutan & - & - & - & - & - & - & 100 \\
\hline Maldives & 25 & 20 & 26 & 12 & 08 & 09 & 100 \\
\hline
\end{tabular}

Source: Respective banks' annual reports and CSR reports

$\mathrm{ED}=$ Education, $\mathrm{HE}=$ Health, $\mathrm{DR}=$ Disaster relief, $\mathrm{PSL}=$ Priority sector lending, $\mathrm{END}=$ Entrepreneur development.

Under the CSR activities banks have taken different initiatives such as education, health, disaster relief, priority sector lending entrepreneur development etc. Above Table 06 shows that for CSR contribution every bank in SAARC countries has emphasized on education than health sector and than other sectors. Nepal and Bhutan have not mentioned their annual CSR report distribution of CSR expenditure. In education sector main CSR activities are scholarship, donation, health sector main activities donation and sponsor, disaster relief sector main activities are relief and donation. Under the CSR activities, for entrepreneur development every bank has taken various CSR initiatives such as training, search new entrepreneur, low interest loan etc. It is sure that by CSR activities, every SAARC countries banks' have ensured sustainable development.

\section{Findings}

1. The study found that out of eight countries only one country (India) has CSR Act. In India CSR activities have operated mandatory basis and rest of SAARC countries CSR activities operated voluntary basis. In Pakistan has CSR regulation but they operated CSR activities voluntary basis.

2. They study found that only one country (Bangladesh) banks have enjoyed tax rebate facilities for CSR expenditure and Central bank of Bangladesh has published annual CSR report of commercial banks in Bangladesh and Central bank of Bangladesh has contributed directly for CSR expenditures.

3. The study also found that all SAARC countries have followed partially international CSR guideline for CSR reporting such as, GRI, UNGC, ISO 14000 for environmental management system, SA 800 for social accountability standards, PSESS by International Financial Corporation and ISO26000netc.

4. The study indicated the percentages of banks for each country which provided minimal, medium and extensive CSR reporting. The picture is of a wide range of experience, from Bangladesh where 83 percent medium and 07 percent extensive of CSR reporting. In India, 55 percent banks medium, 45 percent banks minimal but no extensive of CSR reporting. Only one in eight SAARC countries banks CSR reported at the extensive level. Overall, though, the percentage of banks reporting their CSR extensively and medium were relatively low. Most of the SAARC countries banks have reported CSR minimal level.

5. The study observed that there is a similarity among all SAARC countries sectors of national involvements of CSR initiatives. Every country bank's have emphasizes on social development than employee welfare. By CSR activities, every bank has ensured social development.

6. The study found that for CSR contribution every bank in SAARC countries have emphasized on education sector, health sector and then other sectors. Nepal and Bhutan have not mentioned their annual CSR report distribution of CSR expenditure. In education sector main CSR activities are scholarship, donation, health sector main activities donation and sponsor, disaster relief sector main activities are relief and donation. Under the CSR activities, for entrepreneur development every bank has taken various CSR initiatives such as training, search new entrepreneur, low interest loan etc. It is sure that by CSR activities, every SAARC countries banks' have ensured sustainable development.

\section{Conclusion and Recommendations}

Business houses all over the world are realizing their stake in the society and engaging in various social and environmental activities. The need of the hour is to formulate effective strategic policies and adopt various instruments according to the banking activities, its content, peculiarity in relationship with its different stakeholders so that CSR can be best implemented towards its goals - sustained environmental, social and economic growth. It was analyzed that the reporting practices range from the very sophisticated and wellestablished system to "a brief mention of CSR" in the annual report. CSR reporting will continue to improve 
globally, but the information it contains would need to be standardized. A feature noticed in the development of CSR reporting is the influence of several international and local organizations with different frameworks, indices, directives and initiatives etc. Many of these initiatives are voluntary but are likely to hinder rather than assist the development in the reporting systems. Today's economic framework gives little encouragement for companies to consider the long-term - the essence of true sustainable development.

Banking sector in SAARC countries have involved in diverse issues such as healthcare, education, rural development, sanitation, microcredit, and women empowerment. Analysis of several surveys in SAARC countries banking sector CSR activities suggest that though many banks in SAARC countries have taken on board the universal language of CSR. Individual banks define CSR in their own limited ways and contexts. The end result being that all activities undertaken in the name of CSR are mainly philanthropy, or an extension of philanthropy. It seems that CSR in SAARC countries have been evolving in domain of profit distribution. There is a need to increase the understanding and active participation of business in equitable social development as an integral part of good business practice.

Out of Eight countries, only one country (India) has CSR act and mandatory CSR. Most of the SAARC countries have operated their CSR activities on the voluntary basis but every country of SAARC follow GRI guideline for CSR reporting. There is no doubt have made significant contributions towards the sustainable development of SAARC countries. Considering the limitations of the corporate in their CSR activities, some recommendations which can be used towards satisfaction like banks should extend their CSR activities in less privileged areas rather than concentrate in resource rich areas. It is essential that banks develop an effective value chain system of their products through their CSR activities, which is essential for competing in the global market. It will give better results if activities are based on a more practical \& participatory approach and touch the grassroots level. Voluntarism among employees should be encouraged and institutionalized through recognition and incentives. There is also need for public-private partnership with well-defined controls and process for the best use of resources for social change. Special training needs to be given to business managers in working with social issues. Participation of small and medium business should be encouraged. Experience has shown that working with NGOs is more worthwhile and result-oriented. Joining hands with related NGOs is therefore advisable.

\section{References}

Adhikari, D. R. (2012). Status of Corporate Social Responsibility in selected Nepalese Companies. Corporate Governmance, Vol. 12 (5), pp 642-655.

Afghanistan, G. O. (2005). Social Policy Guidelines for Mining Sector in Afghanistan. Khabul: Afghanistan Government.

Ali, I., Rehman, K. U., \& Yilmaz, A. K. (2010). Effects of corporate social responsibility on consumer retention in cellular industry of Pakistan. African Journal Business and Management, Vol. 4(4), pp 475-485.

Arshad, A. (2006). Corporate reputation and philanthropy. Journal of Human Resource Management, 15(10), pp. 1701-19.

Bank, T. W. (2007). State Owned Enterprises and Corporate Governance. South Asia Region: World bank.

Belal, A. K., Heesam, K., \& Daniel, C. (2015). Afghan-Americans' Understanding, Perception, and Commitment to Corporate Social Responsibility in Afghanistan: A Study Based Upon Gender, Generational Affiliation, and Leadership Experience. Open Ethics and Law Journal, Vol. 1, (Suppl 1: M3), pp 17-23.

Bennett, J. (2009). Country Programme Evaluation Afghanistan. Department for International Development.

Bhutan, B.O. (2012). Bank of Bhutan News Letter. Thempu: Bank of Bhutan.

Biggs, S., \& Messerschmidt, D. (2005). Social Responsibility in the Growing Handmade Paper Industry of Nepal. World Development, Vol.33 (11).

Chambers, E., \& Chapple, W. (2003). CSR in Asia:A seven country study of CSR website reporting. Nottingham: International Centre for Corporate Social Responsibility.

Chapagain, B. R. (2010). Corporate Social Responsibility: Evidence from Nepalese Financial Service and Manufacturing Sectors. Economic Journal of Development Issues, Vol. 11(2).

Chapagain, B. R. (2010). Corporate Social Responsibility: Evidence From Nepalese Financial Service And Manufacturing Sectors. Economic Journal of Development Issues, Vol. 11, No.1.

David, A. W., \& Mary, S. L. (2006). Cultural and leadership predictors of corporate social responsibilviatluyes of top management a GLOBE study of 15 countries. Journal of International Business Studies, Vol.37,pp 823-837.

Dhungel, A. (2009). Corporate Social Responsibility Reporting Pravtices in the Banking Sector of Nepal. Banking Journal, Vol.3.

Gautam, R., \& Anju, A. (2014). Corporate Social Responsibility Practices in India: A Study of Top 500 Companies. Global Business and Management Research: An International Journal, Vol. 2, No. 1, pp. 4156. 
Ismail, M. B. (2012). Corporate Social Responsibility in People's Bank (PD) of Sri Lanka . Research Paper Management, Vol.1 Issue 11.

Kafle, P., \& Tiwari, D. (2014). The Assessment Of A Nepalese Bank In Terms Of Corporate Social Responsibility (CSR). International Journal of Pharmaceutical Sciences and Business Management, Vol.2 Issue. 1, pg. 28-34.

Katuwal, S. B. (2010). A Discourse on Corporate Social Responsibility in Nepal. journal of Management.

Khan, M., \& Majid, A. (2013). Corporate Social Responsibility and Corporate Reputation: A Case of Cement Industry in Pakistan. Interdisciplinary Journal Of Contemporary Research In Business, Vol.5, No.3.

Kostyuk, A. N., \& Mozghovyi, Y. I. (2003). Corporate Social Responsibility In Banks:An International Overview. Ukrainian : Ukrainian Academy of Banking.

Nazir, M. S. (2009). Corporate Social Disclosure in Pakistan: A Case Study of Fertilizers Industry. The Journal of Commerce, Vol. 2, No. 1.

Qazi1, S. W., \& Ahmed, M. (2015). Company's financial performance \& CSR: Pakistan context. Global Advanced Research Journal of Management and Business Studies, Vol. 4(5) pp. 196-202.

Sameer, A. A. (2012). Strategic CSR in Afghanistan. Copenhagen: Centre for Business and Studies.

Shakya, U. R. (2009). Ethics in Nepalese Civil Services Sector: How does it matter? Administration and Management Review, Vol. 21 (2).

Shareef, F., \& Sodique, H. (2010). Baseline Study on Corporate Social Responsibility Practices in Maldives. Male" Maldives.: FJS Consulting Pvt Ltd.

Sharma, E., \& Mani, M. (2013). Corporate Social Responsibility: An Analysis Of Indian Commercial Banks. AIMA Journal of Management \& Research, 7(4).

Visser, W. (n.d.). Corporate Social Responsibility in Developing Countries. Chapter 21.

Waheed, A. (2005). Corporate Social Responsibility In Pakistan And A Strategy For Implementation. Lahore: Responsible Business Inatiatives.

Wijesinghe, K. N. (2013). Impact of Disclouser of Corporate Social Responsibility on Corporate Financial Performance in Bank, Finance and Insurance Sector in Sri Lanka. Journal of Corporate Citizenship, Vol.5(2), pp 123-133.

Yawar, H. M. (1990). CSR Pakistan evolution, rise and impact of socio-economic development Capital Business (Pvt) Ltd. Lahore, Pakistan: Gulberg III.

Yeung, S. (2011). The Role of Banks in Corporate Social Responsibility. Journal of Applied Economics and Business Research, Vol. 1(2): 103-115. 